\title{
Singular-Plural Distinction in Izon and its Influence on the Teaching/Learning of Plural Formation in English
}

\author{
Uriel Okunrinmeta $^{1}$ \\ ${ }^{1}$ Department of English Studies, Adekunle Ajasin University, Ondo State, Nigeria \\ Correspondence: Uriel Okunrinmeta, Department of English Studies, Adekunle Ajasin University, PMB 001, \\ Akungba-Akoko, Ondo State, Nigeria. E-mail: urielok3@yahoo.com
}

Received: March 7, $2013 \quad$ Accepted: April 3, $2013 \quad$ Online Published: May 2, 2013

doi:10.5539/jel.v2n2p126 URL: http://dx.doi.org/10.5539/jel.v2n2p126

\begin{abstract}
This study examines singular-plural distinction processes in Izon and highlights the difficulties these may pose to the teaching and learning of plural formation in English so as to suggest ways in which teachers can design an effective teaching method to tackle the perceived difficulties. The study, which made use of 100 subjects of an average age of eleven years drawn from the Arogbo-Izon community of Ondo State, Nigeria, reveals that Izon inhibits the learning of plural formation in English as the majority of the subjects exhibit the influence of the aplurality marker and the reflexive pronoun formation process in Izon thereby pluralizing all English nouns through the addition of $-\boldsymbol{s}$ and deriving the reflexive pronoun (their selfs or their selves) through the addition of self to the possessive form of the pronoun (their) as against the object form (them) preferred in English. To ensure that the subjects are assisted to overcome these difficulties, the study employs a ten-step contrastive approach which proves very effective as the subjects' performances, after the application of the method, recorded a tremendous rise in the percentage of correct responses from 26 per cent to 94 per cent (plural formation in nouns) and from 46 per cent to 100 per cent (plural formation in pronouns). The method is, therefore, recommended for the teaching of English in the Izon communities in Nigeria and in other similar ESL situations both within and outside Nigeria.
\end{abstract}

Keywords: Bilingualism, second-language, teaching, methodology, Izon

\section{Introduction}

English, Nigeria's most important and, perhaps, most useful colonial legacy (Bamgbose, 1971: 35), occupies a unique place in Nigeria's multilingual setting because of its significant role and status in national life. As Nigeria's official language, English has, according to Adetugbo (1979: 167), come to be seen as "the country's most important language" because of the several significant functions it performs, especially in government, politics, education, business, the mass media, science and technology, international relations, inter-ethnic communication, and national unity, national consciousness and cultural awareness (Adekunle, 1995; Jowitt; 1995; Awonusi, 2004a and Owolabi, 2007). Adegbite (2009: 74 \& 75) summarizes the roles that English plays generally in Nigeria thus:

It serves educational and administrative purposes ... complements the indigenous languages which serve as mother tongues of different people as a further means of preserving, recording and exploring the world ... enables the learner to know more people and understand information about other people's cultures ... It serves some vital economic roles: providing opportunities for gainful employment, requirements for admission into tertiary institutions and opportunities for speakers, writers and media practitioners and artistes to gain access to a wider audience ... It is used for personal and social communication and interaction at the local, inter-ethnic and international levels ... The knowledge of English confers social advantage and an enhanced social status on an individual ... It helps to project the indigenous language culture internationally...

Considering the several significant functions that English performs in Nigeria, it is not surprising that so much attention and resources have over the years been devoted to its teaching in Nigerian schools at the expense of the Nigerian languages (Adeniran, 1978; Adekunle, 1995; Akere, 1995; Awonusi, 2004a and Awonusi, 2004b). In spite of the preference, attention and resources that the teaching of English enjoys in Nigeria, however, it is quite disappointing, as Amuseghan (2007: 320) notes, that there is a remarkable decline in both communicative and 
linguistic competence of the learners of English in Nigeria. As Akere (1995: 180) observes, there is evidence everywhere in the educational system that the standard of English expressions is very poor and that pupils lack the required language skills to cope with both the learning and the communicative tasks at the various levels of education. Mohammed (1995: 138) reports that there has been a steady decline in the performance of students in English Language in the West African Senior School Certificate Examinations and that, between 1988 and 1992, the percentage of failure was high and consistent as it stood between $70 \%$ and $75 \%$ annually in this five-year period. Similarly, in 1997, only $6.54 \%$ of the candidates who took the examinations got credit passes in English Language, while nearly 67\% had outright failure (Bamgbose, 2001 and Uzoezie, 2004). Asikhia (2010: 230) also reports that only $29.59 \%, 25.36 \%, 34.48 \%$ and $29.94 \%$ passed English Language at credit level in the West African Senior School Certificate Examinations in 2004, 2005, 2006 and 2007 respectively. While announcing the release of the 2012 May / June West African Senior School Certificate Examinations results at a media briefing in Lagos ${ }^{1}$ on 10th August, 2012, Dr. Iyi Uwadiae, the head of the Nigerian National Office of the West African Examinations Council, stated that $38.1 \%$ of the candidates who sat for the examination had credits in at least five subjects, including English Language and Mathematics. This, according to him, was better than what was obtained in 2010 when only $23.71 \%$ passed at least five subjects, including English Language and Mathematics, at credit level, and in 2011 which recorded only $30.91 \%$. This high rate of failure is alarming and has, therefore, become a genuine source of concern to all stakeholders in the educational sector: government, teachers, parents and students, to mention just a few. Thus, all hands are on deck to find out the problems which cause this dismal performance in English in the educational system so as to proffer solutions to them.

One of the problems often identified, however, is poor teaching method (Orji, 1987; Afolayan, 1995 and Adegbite, 2009), arising especially from the inability of language teachers to devise an effective pedagogical approach to tackle the difficulties and errors caused by negative transfer from $\mathrm{L}_{1}$ to $\mathrm{L}_{2}$. In the Nigerian multilingual setting where there are over 250 ethnic groups and 350 indigenous languages, most Nigerian learners of English are expected to have possessed the knowledge of their respective MTs before they are exposed to the English language which is usually learnt at school later in life. According to Adegbite (2009: 75), the process of acquisition of the first language in Nigeria begins in infancy, at birth; and the child achieves competence at about five years. In contrast, learning English as $\mathrm{L}_{2}$ begins, for the majority, at the primary school at age five. Unlike the $L_{1}$ speaker who learns language fresh, the Nigerian learner of English as an $L_{2}$ is a "linguistic adult" who has already had some mastery of his / her $\mathrm{L}_{1}$ before learning the $\mathrm{L}_{2}$. Since the Nigerian languages are acquired at an earlier age and with far greater thoroughness than English, it is also expected that certain aspects of the Nigerian languages will interfere with corresponding aspects of the English that is learnt and used by Nigerians (see Bamgbose, 1971: 41; Kirk-Greene, 1971: 141, Adekunle, 1979 and Okunrinmeta, 2008). This view is hinged on the assumption that $\mathrm{L}_{2}$ acquisition is determined by the learner's knowledge of his/her $\mathrm{L}_{1}$ because, as the learner learns the $\mathrm{L}_{2}$, he/she transfers, either positively or negatively (Lado, 1957), aspects of the $L_{1}$ to the $L_{2}$. If the knowledge of $L_{1}$ helps or facilitates the learning of $L_{2}$, there is a positive transfer, which is known as 'facilitation'. If, however, the knowledge of $\mathrm{L}_{1}$ inhibits the learning of $\mathrm{L}_{2}$, then there is a negative transfer, which is known as 'interference' (Weinreich, 1953). Thus, the learner's knowledge of $\mathrm{L}_{1}$ either assists the learning of the $\mathrm{L}_{2}$, (especially where there are similarities between the $\mathrm{L}_{1}$ and the $\mathrm{L}_{2}$ ), or inhibits it where there are differences between the two languages thereby resulting in negative transfer of $\mathrm{L}_{1}$ habits to $\mathrm{L}_{2}$. According to Fillmore (1976), learning the second language is ... in the case of the second language learner ... inhibited in some ways by his knowledge of a first language. Prior knowledge of a first language may predispose the learner to look for familiar ways of expressing in the new language meanings he is accustomed to expressing in his first language. He will be inclined to make the kinds of distinctions in the new language - perhaps inappropriately - that were relevant in the first.

This may also imply that where there are differences between the $\mathrm{L}_{1}$ and the $\mathrm{L}_{2}$ of a second language learner and where he/she, because of one difficulty or the other, makes an inappropriate or negative transfer of $\mathrm{L}_{1}$ habits to $\mathrm{L}_{2}$, this may result in errors. Thus, as Lado (1957) and Corder (1975) observe, difficulties and errors in $\mathrm{L}_{2}$ acquisition are attributed to negative transfer of $\mathrm{L}_{1}$ habits ${ }^{2}$. The responsibility of a good teacher in the ESL classroom is, therefore, to ensure that an effective pedagogical approach is designed to assist learners to overcome these errors. In the Nigerian situation where Nigerian learners of English do transfer, rather inappropriately in most cases, their knowledge of the Nigerian languages in the process of learning English, the most effective methodology, as Olagoke (1985) proposes, is the one that gives a detailed description of the English language and compares this to what obtains in the learner's native language. This is where the application of contrastive pedagogy becomes necessary. However, as Awobuluyi (2009) observes, most of the teachers of English in Nigeria have no training in contrastive linguistics and, therefore, are unable to understand and consequently devise effective pedagogical strategies for combating the mostly mother-tongue induced kinds of 
learners' errors that recur in their pupils' written and oral performances in the language. Even where some of them have the knowledge of contrastive linguistics, the prevailing atmosphere in some Nigerian ESL classrooms does not encourage the use of the approach. As Adegbite (2009: 80) notes, "in certain schools, indigenous languages, pejoratively called vernaculars, are highly prohibited in preference for English" and, thus, making it practically impossible to make any reference to any Nigerian language when teaching English in such schools. However, if English must be effectively taught in the Nigerian ESL classroom where the majority of the learners have already mastered the systems of the mother tongue (the Nigerian languages), it is necessary for teachers to go a step further to tap the rich resources provided by the learners' knowledge of the Nigerian languages since, according to Adegbite (2009: 88), previous learning experiences serve as input which may facilitate the learning of the $\mathrm{L}_{2}$, especially when these previous experiences are positively manipulated to the learners' advantage. It is against this background that this study experiments the teaching of plural formation in English in the Nigerian ESL situation. Specifically, the study examines singular-plural distinction processes in Izon $^{3}$, highlights the difficulties these may pose to the teaching and learning of plural formation in English and suggests ways in which teachers can design an effective teaching method to tackle the perceived difficulties.

\section{Research Procedure}

This study focuses on the teaching / learning of plural formation in English in the Nigerian ESL classroom and, thus, employs the contrastive pedagogical approach to second language teaching to highlight the difficulties that the differences between the learners' $\mathrm{L}_{1}$ (Izon) and $\mathrm{L}_{2}$ (English) may pose to the effective learning of plural formation in English. For the language teacher in the Nigerian ESL classroom to effectively teach the grammatical rules of English, it is necessary, as Olagoke (1985) observes, to give a detailed description of the target language (English) and compares this to what obtains in the learners' native language. Thus, the study employs a ten-step contrastive pedagogical approach in which the rules of plural formation in English are compared to those in Izon so as to assist the learners to overcome the difficulties arising from the differences between the two languages and the resultant errors these may cause.

To achieve this, the study made use of 100 Junior Secondary School (JSS 1) students of an average age of eleven years, who speak only Izon and English and have lived within the Izon culture for at least five years, drawn from four secondary schools in the Arogbo-Izon community of Ondo State, Nigeria. The schools selected are: Arogbo City Academy, Arogbo (with a total population of 60 JSS 1 students); Community Grammar School, Biagbini (56 students); Ukparamah Grammar School, Bolowoghu (58 students) and; Ijaw National High School, Arogbo (76 students), thereby producing a total population size of 250 JSS 1 students. The 100 subjects used for the study were randomly sampled through the following sampling procedure. A ten-item questionnaire was designed to ascertain the subjects' linguistic and cultural background. A total of 250 questionnaires were administered. After observing the responses of each respondent, it was realized that 16 out of the 250 JSS 1 students failed to meet the requirement since they do not speak only Izon and English and have not lived within the Izon cultural environment for up to five years. Thus, the number dropped from 250 to 234: Arogbo City Academy, Arogbo (56 students); Community Grammar School, Biagbini (53 students); Ukparamah Grammar School, Bolowoghu (55 students) and; Ijaw National High School, Arogbo (70 students). The names of all the 234 JSS 1 students were copied out from the class register in each of the four schools selected for the study. 25 students whose names coincided with the multiples of two occurring between one and fifty were then picked from each of the four sampled schools. The sample consisted of 53 boys and 47 girls.

The 100 subjects sampled for the study were given a twenty-item plural formation exercise in English to ascertain the extent to which the differences in singular-plural distinction processes in Izon and English can pose difficulties to the learning of plural formation in English in the Izon (Nigerian) environment. Based on the performances of the subjects in this plural formation exercise in English, the subjects were, through a ten-step contrastive method, exposed to singular-plural distinctions in English with reference to various plural formation processes in Izon so as to draw their attention to the sources of the errors they commit in terms of plural formation in English. After a period of two weeks, another twenty-item plural formation exercise was given to the subjects to ascertain their post-exposure performance and, therefore, the degree of effectiveness of the method in the teaching of English in the Nigerian ESL situation.

\section{Singular-Plural Distinction Processes in Izon}

The way singular-plural distinction is made in Izon nouns is different from the way it is done in English nouns. Singular-plural distinction in Izon nouns is usually made in the following ways: 
1) The form of the noun or pronoun itself:

\begin{tabular}{|c|c|}
\hline Singular & Plural \\
\hline kịmị $b o^{4}$ (person) & kịmị abu (people) \\
\hline iyoro bo / iyoro arau (woman) & iyọoro abu (women) \\
\hline yabị (uncle) & yabị oni (uncles) \\
\hline$e(\mathrm{I} / \mathrm{me})(1 \mathrm{st}$ pers.) & wo (we/us) (3rd pers.) \\
\hline$i$ (you) (2nd pers.) & $o$ (you) (2nd pers.) \\
\hline$u$ (he/him) (3rd pers./masc.) & oni (they/them) (3rd pers.) \\
\hline$a$ (she/her) (3rd pers./fem.) & oni (they/them) (3rd pers.) \\
\hline anị (it) (3rd pers./neuter) & oni (they/them) (3rd pers.) \\
\hline ẹnị (my) (1st pers./poss.) & wọnị (our) (1st per./poss.) \\
\hline inị (your) (2nd pers./poss.) & oni ${ }^{5}$ (your) (2nd pers./poss.) \\
\hline uni (his) (3rd pers./masc./poss.) & oni (their) (3rd pers./poss.) \\
\hline anị (her) (3rd pers./fem./poss.) & onị (their) (3rd pers./poss.) \\
\hline$a n i^{6}$ (its) (3rd pers./neuter/poss.) & oni (their) (3rd pers./poss.) \\
\hline
\end{tabular}

2) Definite articles:

\section{Singular \\ tobou bei/ tobou ma (the child) \\ zei bei (the husband) \\ ere arau ma (the wife)}

yaforo ma (the mother-in-law)

aga $m i$ (the behaviour)

kịmi bo mi (neuter) (the person)

3) Certain demonstratives:

\section{Singular}

bei kuwi bei (this star)

bei isono bei (this ant)

ma yin ma (this mother)

ma ere arau ma (this wife)

mi fere $m i$ (this plate)

mi buru mi (this yam)

u bei kuwi bei (that star)

u bei isono bei (that ant)

u ma yin arau $m a$ (that mother)

$u$ ma ere arau ma (that wife/woma

u mi fere mi (that plate)

u mi buru mi (that yam)

\section{Plural}

owou ma (the children)

zei oni ma/zei abu ma (the husbands)

ere $a b u m a^{7}$ (the wives)

yaforo abu ma (the mothers-in-law)

aga ma (the behaviours)

kimi abu ma (the people)

\section{Plural}

ma akuwị ma (these stars)

ma isono ma (these ants)

ma ayin abu ma (these mothers)

ma ere abu ma (these wives)

ma afere $m a$ (these plates)

ma aburu ma (these yams)

u ma akuwi ma (those stars)

u ma isono ma (those ants)

u ma ayin abu ma (those mothers)

4) The affix a- plurality marker:

In Izon, especially in the Arogbo-Izon dialect, $\boldsymbol{a}$ is usually prefixed to a singular consonant-initial noun when it is preceded by the qualifying forms of the numerals two to twenty-nine ${ }^{8}$ e.g.,
ma akịi (two men)
tara awari (three houses)
nininẹn azruru (eight rooms)
isẹna fere (nine plates)
oi sorọn azarau fin $i^{10}$ (fifteen friends)
oi sidiyo abịde fini (sixteen cloths/ dresses) 
si ma aduhin fịnị (twenty-two nights) Si tara abele fịni (twenty-three pots)

si nininẹn adụwẹ fịni (twenty-eight corpses) si isẹna kịi fịni (twenty-nine times)

Sometimes, a singular vowel-initial noun, which does not begin with the letter $\boldsymbol{a}$ may take the $\boldsymbol{a}$ plurality marker as a prefix when such a noun is preceded by the qualifying forms of the numerals two to twenty-nine e.g.,

sorọn aidi (five fishes)

oi aobori (ten goats)

oi sọọn auku fịni (fifteen lice)

si sidiyo aebe fini (twenty-six pots) sidiyo aidou (six breasts)

oi nin aọana fini (fourteen sheep(s))

si aekpurụ (twenty shoes)

si nininẹn augo finị (twenty-eight eagles)

But when a singular vowel-initial noun begins with letter $\boldsymbol{a}$, the $\boldsymbol{a}$ plurality marker is usually elided when the noun is preceded by the qualifying forms of the numerals two to twenty-nine e.g.,

ma aga (two behaviours)

oi ama (ten towns)

si sọọn aru fini (twenty-five shirts) sọọn adi (five faces)

si aru (twenty canoes)

si sonoma atuta fịnị (twenty-seven onions)

It should, however, be noted that from suwei (thirty) through suwei isen fịni (thirty-nine), the a plurality marker is usually dropped while the qualifying forms of the numeral occur after the noun ${ }^{11}$ which may begin with a consonant or a vowel, e.g.,

kịmi suwei (thirty men)

zei suwei mamụn fịni (thirty-two husbands)

kuraị suwei nin fịni (thirty-four years)

zuru suwei sidiyo fini (thirty-six rooms)

warị suwei nininẹ fini (thirty-eight houses) aru suwei kenị fịni (thirty-one shirts)

ere suwei taru fini (thirty-three wives)

isono suwei sorọn fịni (thirty-five ants)

ogumu suwei sonoma fini (thirty-seven frogs)

abirei suwei isen fịni (thirty-nine brothers)

But from mesi (forty) upwards, the $\boldsymbol{a}$ becomes prefixed to the numeral and both the prefix $\boldsymbol{a}$ and the noun, whether consonant-initial or vowel-initial, precede the qualifying forms of the numeral e.g.,

kuraị amesi (forty years)

kịị atara asi (sixty men)

kasị anin asi oi fịnị (ninety chairs)

zei aoi asi (two hundred husbands)

buru asoron ode (two thousand yams)

oko aoi soron ode fini (six thousand cups) zuru amesi oi fini (fifty rooms)

ere anin asi (eighty wives)

otolo asoron asi (one hundred flies)

fun ama ode (eight hundred books)

ololo aoi ode (four thousand bottles)

bele asi ode (eight thousand pots)

However, when the qualifying forms of the numeral begin with ode, (that is, multiples of four hundred), the $\boldsymbol{a}$ plurality marker may be prefixed to the second element of the qualifying numeral e.g.,

wari ode amesi (sixteen thousand houses)

ekpuru ode amesi taru fini (seventeen thousand and two hundred shoes)

kasi ode amesi sorọn fịni (eighteen thousand chairs)

iye ode amesi oi fini (twenty thousand things)

aru ode amesi oi mamun fini (twenty thousand and eight hundred canoes)

aru ode atara si (twenty four thousand shirts)

duhin ode atara si oi sorọn fịni (thirty thousand nights)

pouye ode anin asi (thirty-two thousand stones/rocks)

ofoni ode anin asi isẹn fịni (thirty-five thousand and six hundred hens/cocks)

oporopo ode asoron asi (forty thousand pigs)

ere ode asoron asi oi keni fini (forty-four thousand and eight hundred wives)

ere ode asidiyo asi (forty-eight thousand names)

kana ode asidiyo asi sorọn fini (fifty thousand cages) 
It is also important to note the following:

kẹni buru igbedi (one million yams)

ma azuru igbedi (two million rooms)

tara awari igbedi (three million houses)

sidiyo akasi igbedi (six million chairs)

oi akuwi igbedi (ten million stars)

si adiriaberi igbedi (twenty million leaves)

kẹni duhin opu igbedi (one billion nights)

oi afun opu igbedi (ten billion books)

si azei opu igbedi (twenty billion husbands)

The $\boldsymbol{a}$ plurality marker may also be prefixed to a singular noun, whether consonant-initial or vowel-initial, co-occurring with a prenominal qualifier which may be a quantifier, a demonstrative, a possessive or an adjective $^{12}$ e.g.,

\section{(i) Quantifiers}

zuwa awari (some houses)

zuwa aekpuru (some shoes)

zuwa afun (some books)

zuwa aobori (some goats)

buhin akimi (many men)

buhin aidi (many fishes)

buhin akasị (many chairs)

buhin aidou (many breasts)

tara azei (three husbands)

nin aisono (four ants)

sorọn ayabị (five uncles)

oi aotololo (ten flies)

(ii) Demonstratives

ma aburu ma (these yams)

u ma aburu ma (those yams)

ma aidi $m a$ (these fishes)

ma abira ma (these hands)

u ma aidi ma (those fishes)

u ma abira ma (those hands)

ma atoru ma (these eyes)

u ma atoru ma (those eyes)

ma aekpuru ma (these shoes)

u ma aẹpuru ma (those shoes)

(iii) Possessives

ẹnị awarị (my houses)

ẹni aidou (my breasts)

inị azuru (your rooms)

inị aobori (your goats)

unị akasị (his chairs)

unị aogigan (his doors)

ani abira (her hands)

ani aofini (her fowls)

woni abịde (our cloths/dresses)

wonị aonana (our sheeps)

oni ${ }^{13}$ akurai (your years)

oni aidi (your fishes)

oni afun (the books)

oni auku (their private parts)

(iv) Adjectives

uku atịn (heavy sticks)

dubulu akimi (plump men)

lẹlu auku (dirty private parts)

ikị abịde (stained cloths/dresses)

pinyon pinyọn aidou (pointed breasts)

dahain azei (tall husbands)

ebi aidi (good fishes)

buru aburu (rotten yams)

sei aere (bad wives)

bịra suwo aebe (cheap pots)

pịna akasị (white chairs)

wowo adiriaberi (red leaves)

The $\boldsymbol{a}$ plurality marker may also be prefixed to a consonant-initial plural noun co-occurring with a prenominal qualifier e.g.,

buhin adau abu (many fathers)

ma akimi abu ma (these people)

enị adau abu (my fathers)

ebi azei abu (good husbands) zuwa azowei abu (some friends)

u ma atinimo abu ma (those teachers)

woni ayin abu (our mothers)

sei abuna abu (bad relations) 
But when the plural noun co-occurring with the prenominal qualifier is vowel-initial, the $a$ plurality marker becomes elided e.g.,

$\begin{array}{ll}\text { sei ere abu (bad wives) } & \text { ebi iyoro abu (good women) } \\ \text { buhin owou (many children) } & \text { zuwa owei abu (some men) } \\ \text { woni ere abu (our wives) } & \text { dahaịn owei owou (tall boys) }\end{array}$

\section{The Teaching/Learning of Plural Formation in English in the Izon Setting}

Singular-plural distinction processes in Izon, as shown in the preceding section, are different from those in English where, apart from the $-\boldsymbol{s}$ suffix which most English nouns employ to indicate plurality, some other singular-plural distinction techniques are employed. ${ }^{14}$ To ascertain the extent to which these differences in singular-plural distinction processes in Izon and English can pose difficulties to the learning of plural formation in English in the Izon environment, the subjects were given an exercise where they were told to give the plural forms of the following nouns and pronouns:

$\begin{array}{lllll}\text { goat } & \text { lion } & \text { nose } & \text { watch } & \text { fly } \\ \text { party } & \text { leaf } & \text { knife } & \text { wife } & \text { thief } \\ \text { foot } & \text { louse } & \text { mouse } & \text { child } & \text { sheep } \\ \text { oil } & \text { information } & \text { himself } & \text { herself } & \text { itself }\end{array}$

52 of the subjects, (that is, 52 per cent), pluralized all the nouns through the addition of the $-s$ suffix thereby indicating that the subjects treated the -s plurality marker in English as equivalent to the $a$ - plurality marker in Izon which almost all ${ }^{15}$ plural nouns in Izon must take to indicate plurality. However, the remaining 48 subjects, (that is, 48 per cent), indicated plurality correctly in varying degrees, especially in those nouns which do not require an -s for plural formation. Specifically, 26 of the 48 subjects pluralized all the nouns correctly while the remaining 22 had problems with the non-count nouns which they also pluralized by adding an -s.

Similarly, 52 of the subjects, (that is, 52 per cent), used the form their selfs as the plural of himself, herself and itself instead of themselves, while 2 subjects ( 2 per cent) used their selves, thereby bringing the total number of incorrect responses to 54 per cent. This substitution of their selfs or their selves for themselves, as Okunrinmeta (2011) notes, is traceable to the Izon language where all reflexive pronouns are derived by adding ozu (self) to the possessive forms of the pronouns e.g.,

$$
\begin{array}{ll}
\text { ẹni ozu (my self) } & \text { inị ozu (your self) } \\
\text { woni ozu (our self) } & \text { onị ozu (their self) } \\
\text { unị ozu (his self) } & \text { anị ozu (her self) }
\end{array}
$$

Since them is an object pronoun, it is incorrect in Izon to say o ozu (themself). This is why oni ozu (their self) and its plural oni aozu (their selfs) are preferred in Izon.

Two difficulties have been identified here. The first, as indicated in the performances of 52 per cent of the subjects, is the pluralization of all English nouns, (including those that do not indicate plurality through the $-\boldsymbol{s}$ suffix), by adding $-\boldsymbol{s}$ to the singular form of the noun, which is traceable to the predominant use of the aplurality marker in Izon. The second is the derivation of the reflexive pronoun (their selfs or their selves) through the addition of self to the possessive form of the pronoun (their) as against the object form (them) preferred in English. This is reflected in the performances of 54 per cent of the subjects where the reflexive pronoun, their selfs (52 per cent) or their selves ( 2 per cent), occurred.

The challenge of the English teacher is therefore to design an appropriate methodological approach that can be used to effectively tackle the errors that arise from the differences between the two languages (Izon and English). The most effective methodology, as Olagoke (1985) proposes, is the one that gives a detailed description of the target language (English) and compares this to what obtains in the learner's native language (Izon). This is what this study experiments. The 100 subjects sampled for the study were exposed to singular-plural distinctions in English with reference to various plural formation processes in Izon so as to draw the attention of the subjects to the sources of the errors they commit in terms of plural formation in English. The methodology employed in this study follows the following procedure:

Step 1: The nouns and pronouns given to the subjects earlier were listed and each of the subjects was called upon to read them.

Step 2: The subjects were told that, in Izon, all these nouns and pronouns can be pluralized through the a- 
plurality marker e.g.,

\begin{tabular}{|c|c|}
\hline kẹnị obori (one goat) & oi aobori (ten goats) \\
\hline wonị bousei (our lion) & wọnị abuosei (our lions) \\
\hline ẹnị nini (my nose) & oni anini (their noses) \\
\hline kenị ira di iye (one watch) & si aira di aiye (twenty watches) \\
\hline buru otolo (rotten fly) & buru aotolo (rotten flies) \\
\hline ebi toi kiri (good party) & ebi atoi akiri (good parties) \\
\hline kẹnị diriberi (one leaf) & si adiriaberi igbedi (twenty million leaves) \\
\hline u mi ẹdẹịn mị (that knife) & u ma soron aẹdẹhị ma (those five knives) \\
\hline sei ere (bad wife) & sei aere (bad wives) \\
\hline kẹni furuwei (one thief) & sidiyo afuruabu (six thieves) \\
\hline lẹlu buwwo (dirty foot) & lẹlu abuwwo (dirty feet) \\
\hline kẹnị uku (one louse) & oi sọrọn auku fịnị (fifteen lice) \\
\hline dubulu oke (plump mouse) & dubulu aoke (plump mice) \\
\hline ebi tọbọ (good child) & ebi aowoụ (good children) \\
\hline dirimo onana (black sheep) & dirimo aọnana (black sheep(s)) \\
\hline kẹnị pulo (one (keg oil) & nininẹn apulo (eight oil(s)) \\
\hline kenị egberi (one information) & oi aegberi (ten information(s)) \\
\hline unị ozu (his self) & onị aozu (their selfs) \\
\hline anị ozu (her self) & oni aozu (their selfs) \\
\hline anị ozu (its self) & onị aozu (their selfs) \\
\hline
\end{tabular}

Step 3: The subjects were also told that since all Izon nouns are pluralized through the a- plurality marker as shown in step 2 above, and since many Izon-English bilinguals are aware of the fact that most English nouns show plurality through the $-\boldsymbol{s}$ suffix, there is a tendency for some Izon-English bilinguals ${ }^{16}$ to interpret the aplurality marker as equivalent to the -s suffix in English and, therefore, to pluralize all English nouns, (including those that do not indicate plurality through the $-\boldsymbol{s}$ suffix), by adding $-\boldsymbol{s}$ to the singular form of the noun. This is, however, misleading because the a- plurality marker is not equivalent to the -s suffix in all instances.

Step 4: The subjects were told that the Izon a- plurality marker may only be interpreted to be equivalent to the -s suffix in English in such English words as goat: goats, lion: lions, nose: noses and watch: watches, which usually show plurality through the addition of -s or -es to the singular. Other examples include:

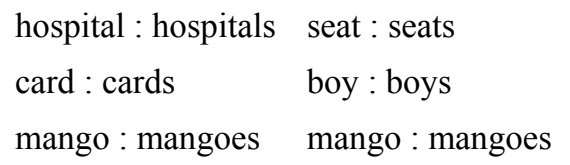

Step 5: In such English nouns as fly, party, leaf, knife, wife, thief, foot, louse, mouse, child, sheep, oil and information which do not show plurality through -s or -es, it is wrong and misleading to interpret the a- plurality marker as equivalent to the -s suffix since some other techniques are applied in these nouns to indicate plurality:

(i) The majority ${ }^{17}$ of nouns which end in $-f$ or $-f e$ usually change this to -ves in their plural forms, e.g.,
leaf: leaves
knife : knives
wife : wives
thief : thieves
calf : calves
half : halves

(ii) In nouns that end in $-y$, the $-y$ changes to $-i e s$ e.g.,
fly: flies
party: parties
lady: ladies
city: cities
baby: babies
lorry: lorries 
(iii) Some nouns also show plurality through vowel change, e.g.,

$\begin{array}{ll}\text { foot: feet } & \text { tooth: teeth } \\ \text { mouse: mice } & \text { louse: lice } \\ \text { man : men } & \text { woman: women }\end{array}$

(iv) There are some nouns in English which show plurality by adding -en to the singular: chid: children ox: oxen

(v) Some nouns which end in -um, -is, -eau, -on or -us usually show plurality by the addition of $-a,-e s,-x,-a$ or $-i$ respectively:

stadium : stadia

analysis : analyses

bureau: bureaux

phenomenon: phenomena

stimulus : stimuli stratum: strata

hypothesis: hypotheses

portmanteau: portmanteaux

criterion: criteria

locus: loci

(vi) There are some nouns which use the same form for singular and plural, e.g.,

$$
\text { sheep: sheep deer: deer }
$$

(vii) There are some nouns in English which are called non-count nouns. These nouns usually indicate plurality by using a suitable count-noun which serves as a descriptive label, e.g.,

$\begin{array}{lll}\text { oil } & \text { a barrel of oil } & \text { two barrels of oil } \\ \text { information } & \text { a piece of information } & \text { some pieces of information } \\ \text { bread } & \text { a loaf of bread } & \text { three loaves of bread } \\ \text { salt } & \text { a pack of salt } & \text { five packs of salt } \\ \text { chalk } & \text { a piece of chalk } & \text { some pieces of chalk } \\ \text { glass } & \text { a sheet of glass } & \text { two sheets of glass } \\ \text { news } & \text { an item of news } & \text { some items of news }\end{array}$

(viii) Such nouns as pants, scissors, shorts, pliers, trousers and glasses, which are usually treated as plural, can be rendered as singular in the following ways:

$\begin{array}{ll}\text { pants } & \text { a pair of pants } \\ \text { scissors } & \text { a pair of scissors } \\ \text { shorts } & \text { a pair of shorts } \\ \text { pliers } & \text { a pair of pliers } \\ \text { trousers } & \text { a pair of trousers } \\ \text { glasses } & \text { a pair of glasses }\end{array}$

Step 6: The subjects were told to take note of the singular and plural forms of the following pronouns:
$\mathrm{I} / \mathrm{me}$ (1st pers.)
we/us (3rd pers.)
you (2nd pers.)
you (2nd pers.)
he/him (3rd pers./masc.)
they/them (3rd pers.)
she/her (3rd pers./fem.)
they/them (3rd pers.)
it (3rd pers./neuter)
they/them (3rd pers.)
my (1st pers./poss.)
our (1st per./poss.)
your (2nd pers./poss.)
your (2nd pers./poss.)
his (3rd pers./masc./poss.)
their (3rd pers./poss.)
her (3rd pers./fem./poss.)
their (3rd pers./poss.)
its (3rd pers./neuter/poss.)
their (3rd pers./poss.) 
$\begin{array}{lr}\text { myself (1st pers./poss.) } & \text { ourselves (1st pers./poss.) } \\ \begin{array}{ll}\text { yourself (2nd pers./poss.) } & \text { yourselves (2nd pers./poss.) } \\ \text { himself/herself/itself (3rd pers./poss.) } & \text { themselves (3rd pers./poss.) }\end{array}\end{array}$

Step 7: The attention of the subjects was drawn to the fact that, in Izon, all reflexive pronouns are derived by adding ozu (self) to the possessive forms of the pronouns: ẹni ozu (my self), ini ozu (your self), woni ozu (our self), oni ozu (their self), uni ozu (his self) and ani ozu (her self). Just like in Izon, the reflexive pronouns myself: ourselves and yourself : yourselves in English are derived by adding -self to the possessive forms my, our and your. But, unlike what obtains in Izon, the third person singular reflexive pronouns himself, herself and itself, as well as the third person plural reflexive pronoun themselves, are formed by adding -self to the object forms him, her ${ }^{18}$, it and them.

Step 8: The subjects were told that Steps 5, 6 and 7 explained why it was wrong to have leaf: leafs, knife : knifes, wife : wifes, thief: thiefs, fly : flys, party : partys, foot : foots, mouse : mouses, louse : louses, child : childs, ox : oxes, sheep : sheeps, deer : deers, oil : oils, information : informations and himself/herself/itself : their selfs.

Step 9: The correct plural forms of the nouns and pronouns listed in Step 1 were copied out and the subjects were led to read them several times. Each subject was also called upon to read them.

Step 10: After a period of two weeks, the following exercise on plural formation was given to the subjects so as to ascertain their post-exposure performance. The subjects were told to provide the plural forms of the following nouns and pronouns:

$\begin{array}{lllll}\text { child } & \text { cup } & \text { loaf } & \text { goose } & \text { yourself } \\ \text { tax } & \text { body } & \text { plateau } & \text { deer } & \text { furniture } \\ \text { equipment } & \text { basis } & \text { rice } & \text { wharf } & \text { myself } \\ \text { sheep } & \text { medium } & \text { radius } & \text { herself } & \text { criterion }\end{array}$

It was noticed that 94 of the subjects, (that is, 94 per cent), pluralized all the twenty words tested in Step 10 correctly. The remaining 6 subjects, (that is, 6 per cent), still had problem with the pluralization of the non-count nouns furniture, equipment and rice and, thus, used $-s$ to pluralize them. A comparison of the subjects' pre-exposure and post-exposure performances shows that the number of correct responses, in terms of plural formation in nouns, rose from the 26 per cent initially recorded to 94 per cent as 68 more subjects were able to pluralize all the nouns correctly. This represents a rise of 68 per cent. Similarly, the number of correct responses, in terms of plural formation in reflexive pronouns, rose from the 46 per cent initially recorded to 100 per cent as all the 100 subjects were able to correctly pluralize the reflexive pronouns yourself, myself and herself as yourselves, ourselves and themselves respectively. This proves that the methodology employed in this study, which gives a detailed description of plural formation in the target language (English) and compares this to what obtains in the learner's native language (Izon) so as to draw the attention of the subjects to the sources of the errors they commit in terms of plural formation in English, is effective since there was, after the application of the method, a considerable improvement in the subjects' performances in the sense that the number of subjects who initially had problem with plural formation in English was drastically reduced.

\section{Conclusion}

The present study explores singular-plural formation processes in Izon so as to ascertain the extent to which these can influence the learning of plural formation in English. Based on the performances of the 100 subjects sampled for the study in a twenty-item plural formation exercise in English, the study reveals that Izon has tremendous influence on the learning of plural formation in English as the a- plurality marker and the reflexive pronoun formation process in Izon affected the way the majority of the subjects pluralized the nouns and reflexive pronouns tested to ascertain the subjects' pre-exposure performances in plural formation in English. To ensure that the subjects are assisted to overcome the difficulties arising from the differences between Izon and English in terms of plural formation, a ten-step contrastive approach, which compares plural formation in Izon and English, was adopted so as to draw the subjects' attention to the errors they commit and to correct them. Two weeks after the application of the method, another twenty-item plural formation exercise was given to the subjects to ascertain their post-exposure performance which showed a tremendous improvement in terms of plural formation in nouns since the subjects recorded 94 per cent of correct responses as against the 26 per cent initially recorded. Similarly, the performance of the subjects in terms of plural formation in pronouns rose from 46 per cent to 100 per cent showing a rise of 64 per cent. The improvement in the post-exposure performances of the subjects indicates that the method is effective and, thus, it is recommended for the teaching of English in the 
Izon-speaking communities in Nigeria and other similar ESL situations both within and outside Nigeria.

\section{References}

Adegbija, E. (2004). The domestication of English in Nigeria. In S. Awonusi, \& E. A. Babalola (Eds.), The domestication of English in Nigeria: A festschrift in honour of Abiodun Adetugbo (pp. 20-44). Lagos: University of Lagos Press.

Adegbite, W. (2009). The psycholinguistics of English language in Nigeria. Ibadan: Kraft Books.

Adekunle, M. A. (1979). Non-random variation in the Nigeria English. In E. Ubahakwe (Ed.), Varieties and functions of English in Nigeria (pp. 27-42). Ibadan: African Universities Press.

Adekunle, M. A. (1995). English in Nigeria: Attitudes, policy and communicative realities. In A. Bamgbose, A. Banjo, \& A. Thomas (Eds.), New Englishes: A West African perspective (pp. 57-86). Ibadan: Monsuro.

Adeniran, A. (1978). Personalities and policies in the establishment of English of Northern Nigeria during the British colonial administration, 1890-1943. Journal of the Historical Society of Nigeria, 9, 105-126.

Adetugbo, A. (1979). Nigerian English and communicative competence. In E. Ubahakwe (Ed.), Varieties and functions of English in Nigeria (pp. 167-183). Ibadan: African Universities Press.

Afolayan, A. (1995). Ineffectiveness in the presentation of English in Nigeria: Sources and remedies. In A. Bamgbose, A. Banjo, \& A. Thomas (Eds.), New Englishes: A West African perspective (pp. 113-129). Ibadan: Monsuro.

Akere, F. (1995). (1995). Languages in the curriculum: An assessment of the role of English and other languages in the education delivery process in Nigeria. In A. Bamgbose, A. Banjo, \& A. Thomas (Eds.), New Englishes: A West African perspective (pp. 178-199). Ibadan: Monsuro.

Akere, F. (2001). English across disciplines: A use of English course text. Ikeja: Pumark.

Amuseghan, S. A. (2007). ESL curriculum in secondary schools in Nigeria: Issues and challenges towards communicative competence. Nebula, 4(2), 319-333.

Asikhia, O. A. (2010). Students and teachers' perception of the causes of poor academic performance in Ogun State secondary schools (Nigeria): Implications for couselling for national development. European Journal of Social Sciences, 13(2), 229-242.

Awobuluyi, O. (2009). Language education in Nigeria: Theory, policy and practice. Fafunwa Foundation Internet Journal of Education. Retrieved from http://fafunwafoudation.tripod.com/fafunwafoundation/id8.html

Awonusi, V. O. (2004a). Cycles of linguistic history: The development of English in Nigeria. In A. B. K. Dadzie, \& S. Awonusi (Eds.), Nigerian English: Influences and characteristics (pp. 46-66). Lagos: Concept Publications.

Awonusi, V. O. (2004b). The functions of Nigerian English in relation to other Nigerian languages. In A. B. K. Dadzie, \& S. Awonusi (Eds.), Nigerian English: Influences and characteristics (pp. 67-81). Lagos: Concept Publications.

Bamgbose, A. (1971). The English language in Nigeria. In J. Spencer (Ed.), The English language in West Africa (pp. 35-48). London: Longman.

Bamgbose, A. (2001). Language policy in Nigeria: Challenges, opportunities and constraints. Keynote address delivered during the Nigerian Millennium Sociolinguistics Conference, University of Lagos.

Christophersen, P., \& Sandved, A. O. (1969). An advanced English grammar. London: Macmillan.

Corder, S. P. (1975). Error analysis, interlanguage and second language acquisition. Language Teaching and Linguistics Abstracts, 8, 201-218. http://dx.doi.org/10.1017/S0261444800002822

Dulay, H. C., Burt, M. K., \& Krashen, S. (1982). Language two. New York: Oxford University Press.

Ellis, R. (1985). Understanding second language acquisition. Oxford: Oxford University Press.

Fillmore, L. W. (1976). The second time around: Cognitive and social strategies in second language acquisition. Ph.D. Diss., Stanford University.

Hamers, J. F., \& Blanc, M. H. A. (1989). Bilinguality and bilingualism. Cambridge: Cambridge University Press.

Hatch, E. M. (1983). Psycholinguistics: A second language perspective. Rowley, Mass: Newbury House. 
Huddleston, R. (1984). Introduction to the grammar of English. Cambridge: Cambridge University Press. http://dx.doi.org/10.1017/CBO9781139165785

Idowu, S. O. (2004). Mother tongue interference: A perceived negative influence utilized for positive second language learning. In S. Awonusi, \& E. A. Babalola (Eds.), The domestication of English in Nigeria: A festschrift in honour of Abiodun Adetugbo (pp. 462-479). Lagos: University of Lagos Press.

Jenewari, C. E. W. (1989). Ijoid. In J. Bendor-Samuel (Ed.), The Niger-Congo languages (pp. 106-118). Lanham: University Press of America.

Jowitt, D. (1995). Nigeria's national language question: Choices and constraints. In A. Bamgbose, A. Banjo, \& A. Thomas (Eds.), New Englishes: A West African perspective (pp. 34-56). Ibadan: Monsuro.

Kirk-Greene, A. (1971). The influence of West African languages on English. In J. Spencer (Ed.), The English language in West Africa (pp. 123-144). London: Longman.

Lado, R. (1957). Linguistics across cultures. Ann Arbor: University of Michigan Press.

McLaughlin, B. (1984). Second-language acquisition in childhood: Volume I. Preschool children (2nd ed.). Hillsdale, N. J.: Erlbaum.

Mohammed, A. (1995). Communicative competence acquisition in infelicitous learning environments: The problem with SSS English in Nigeria. In A. Bamgbose, A. Banjo, \& A. Thomas (Eds.), New Englishes: A West African perspective (pp. 130-152). Ibadan: Monsuro.

Okoro, O. (2004). The identification of standard Nigerian English usage. In A. B. K. Dadzie, \& S. Awonusi (Eds.), Nigerian English: Influences and characteristics (pp. 158-178). Lagos: Concept Publications.

Okunrinmeta, U. (2008). Utilizing perceived pronunciation deficiency for positive second language teaching and learning: The Izon experience. Lagos Review of English Studies, 16(1/2), 256-268.

Okunrinmeta, U. (2011). Izon syntax and the English of Izon-English bilinguals. World Englishes, 30(2), 211-228. http://dx.doi.org/10.1111/j.1467-971X.2011.01699.x

Olagoke, D. (1985). The linguistic errors and their implications for ESL pedagogy. Lagos Review of English Studies, VI/VII.

Orji, N. (1987). English language studies in higher education: Problems and suggestions for improvement. Lagos Review of English Studies, 9, 16-28.

Owolabi, D. (2007). English language as a medium of mass communication in a second language situation: The Nigerian press as an example. UNAD Studies in Language and Literature, 2(2), 57-67.

Richards, J. C. (1974). A non-contrastive approach to error analysis. In J. C. Richards (Ed.), Error analysis: Perspectives on second language acquisition. London: Longman.

Uzoezie, R. U. (2004). The linguistic capital market and attitudinal ambivalence of Nigerians to English as an adopted language. In S. Awonusi, \& E. A. Babalola (Eds.), The domestication of English in Nigeria: A festschrift in honour of Abiodun Adetugbo (pp. 363-382). Lagos: University of Lagos Press.

Weinreich, U. (1953). Languages in contact: Findings and problems. The Hague: Mouton.

Williamson, K. (1968). Languages of the Niger Delta. Nigeria Magazine, 97, 124-130.

Williamson, K., \& Timitimi, A. O. (1983). Short Izon-English dictionary, Delta 3. Port Harcourt: University Press.

\section{Notes}

Note 1. Dr. Iyi Uwadiae's address was retrieved from http://www.waecnigeria.org/pdf/Press_ Release2012.pdf, on November 8, 2012.

Note 2. However, advances in psycholinguistics, especially in the area of $\mathrm{L}_{1}$ and $\mathrm{L}_{2}$ acquisition, have drawn attention to the fact that all errors in $\mathrm{L}_{2}$ acquisition cannot be attributed to $\mathrm{L}_{1}$ interference. There are some errors which stem from the acquisition process itself. These errors are developmental and, thus, intralingual in nature, and not interlingual. According to Richards (1974), they are caused by overgeneralization, ignorance of rule restrictions, incomplete application of rules, or by developing false concepts about $\mathrm{L}_{2}$. He argues that these errors cannot be attributed to $L_{1}$ interference because the same errors are committed by $L_{2}$ learners from different $L_{1}$ backgrounds. Such errors are, therefore, better explained through the recognition of the existence of universal 
developmental sequences which characterize the various developmental stages that the $\mathrm{L}_{2}$ learner, just like the $\mathrm{L}_{1}$ learner, passes through in the process of language acquisition (see Hatch 1983, Dulay, Burt \& Krashen, 1982, McLaughlin, 1984, Ellis, 1985 and Hamers \& Blanc, 1989).

Note 3. zon is one of the seven languages that form the language-cluster called Ijo or Ijaw. Izon is spoken in Ondo, Edo, Delta and Bayelsa States of the oil-rich Niger Delta region of Nigeria. It can be sub-classified into South western (including Arogbo), North western (including Mein), South central (including Bumo) and North central (including Kolokuma) (see Williamson, 1968 and Jenewari, 1989). The Arogbo dialect of Izon is what is used in this study.

Note 4. Kịmi in Izon means man but it may be used as a generic term to cover both men and women as people.

Note 5. Qni (your) is said on a low tone while oni (their) is said on a high tone.

Note 6. Though ani also appears under feminine, it is different neuter ani in this context. While the feminine pronoun ani is uttered with the low tone, its neuter counterpart takes the high tone.

Note 7. $M a$ following the singular noun as in ere ma (the wife), iyoro tobou $m a$ (the girl) etc. indicates femininity, while $m a$ occurring after the plural noun as in ere abu ma (the wives), iyoro owou ma (the girls) etc. indicates plurality.

Note 8. This excludes oi kẹni fịnị (eleven) and si kenni fịni (twenty-one) which do not take a e.g., oi kẹnị kịmị fịni (eleven men) and si kẹni zuru fịni (twenty-one rooms).

Note 9. For isẹn (nine), oi isen fịni (nineteen) and si isẹn fịni (twenty-nine), the $a$ is usually attached as a suffix to the numerals as in isena fẹe (nine plates), oi isena kuwi fini (nineteen stars) and si isena wari fịni (twenty-nine houses).

Note 10. Fifteen is also called diye in Izon.

Note 11. Plurality in this case is usually indicated by the numerals suwei (thirty) to suwei isen fini (thirty-nine).

Note 12. This excludes nouns that begin with the letter $a$.

Note 13. See 4 above for the distinction between oni (your) and oni (their).

Note 14. While most English nouns usually form their plurals through the $-s$ suffix added to the singular form of the noun (e.g., boy: boys, book: books, card: cards), some form theirs through a replacive (e.g., man: men, foot: feet, tooth: teeth), through the addition of the - en suffix (e.g., child: children, ox: oxen) and through zero plurals (e.g., deer: deer, sheep: sheep), among others (see Christophersen \& Sandved, 1969 and Huddleston, 1984).

Note 15. See 11 above.

Note 16. These include especially those whose level of education and exposure to good English is low.

Note 17. However, such nouns as chief and cliff only add -s to the singular to derive the plural forms chiefs and cliffs. Similarly, in such nouns as hoof and wharf, both forms are possible: hoof: hoofs/hooves; wharf: wharfs/wharves.

Note 18. This may not pose any problem to the Izon learner of English because both the possessive form and the object form are written as her. 